\title{
IDENTIFIKASI BAHAYA KECELAKAAN KERJA DI PT.TOSHIN PRIMA FINE BLANKING MENGGUNAKAN METODE JOB SAFETY ANALYSIS DAN HAZARD IDENTIFICATION, RISK ASSESMENT AND RISK CONTROL
}

\author{
Ferry Rakhman ${ }^{1}$, Denny Andesta ${ }^{2}$, Ahmad Waiusr ${ }^{3}$ \\ Teknik Industri, Teknik, Universitas Muhammadiyah Gresik, Sumatera 101 GKB, Gresik 61121 \\ *Email : rakhmanferry@gmail.com
}

\begin{abstract}
Abstrak
PT. Toshin Prima Fine Blanking merupakan perusahaan manufacturing yang bergerak di bidang produksi automotive. Pada proses produksi sering mengalami kecelakaan kerja. karena di perusahaan ini mempunyai potensi kecelakaan kerja yang tinggi akibat berinteraksi langsung dengan mesin - mesin yang mempunyai potensi bahaya yang cukup tinggi sehingga dapat menimbulkan kecelakaan kerja. Penelitian ini bertujuan untuk mencari penyebab terjadinya kecelakaan, Mengetahui nilai atau tingkat risiko bahaya yang ada pada setiap mesin dan memberi usulan pengendalian risiko diarea produksi. Penelitian ini menggunakan metode job safety analysis untuk mengidentifikasi bahaya dan metode Hazard Identification Risk Assessment Risk Control untuk melakukan penilaian seberapa besar tinggi tingkat resiko yang terjadi pada mesin tersebut dan melakukan pengendalian resiko untuk mencegah atau dapat mengurangi kecelakaan kerja pada pekerja. hasil analisis dari permasalahan diatas dapat ditarik kesimpulan bahwa potensi bahaya diarea produksi berasal dari faktor manusia, mesin dan manajemen/sistem perusahaan. Penilaian severity dan likelihood yang digunakan untuk menentukan risk matrik digunakan untuk acuan pengendalian terhadap bahaya yang termasuk dalam medium risk dan high risk melalui usulan pengendalian risiko dengan melakukan pengendalian teknis, administratif dan pengendalian alat pelindung diri.
\end{abstract}

Kata Kunci : Manajemen Risiko, K3, job safety analysis, Hazard Identification Risk Assessment and Risk Control

\begin{abstract}
PT. Toshin Prima Fine Blanking is a manufacturing company engaged in automotive production. In the production process, accidents often occur. because this company has a high potential for work accidents due to direct interaction with machines that have a high enough potential hazard so that it can cause work accidents. This study aims to find the cause of the accident, determine the value or level of hazard risk that exists in each machine and provide suggestions for risk control in the production area. This study uses the job safety analysis method to identify hazards and the Hazard Identification Risk Assessment Risk Control method to assess how high the level of risk that occurs in the machine and carry out risk control to prevent or reduce work accidents for workers. The results of the analysis of the problems above can be concluded that the potential hazards in the production area come from human factors, machines and company management/systems. The assessment of severity and likelihood used to determine the risk matrix is used as a reference for controlling the hazards that are included in
\end{abstract}


medium risk and high risk through risk control proposals by carrying out technical, administrative and personal protective equipment controls.

Keywords: Risk Management, K3, job safety analysis, Hazard Identification Risk Assessment and Risk Control

Jejak Artikel

Upload artikel : 1 Desember 2021

Revisi : 15 Desember 2021

Publish : 31Januari2022

\section{PENDAHULUAN}

\section{PT.TOSHIN PRIMA FINE BLANKING}

merupakan perusahaan yang bergerak di bidang produksi automotive dengan proses produksi menggunakan mesin Fine blanking, Belt sander, CNC lathe, Milling, Mesin pres aida, Rotary grinding dan Mesin Brush. Yang beralamatkan Jl. Margomulyo Indah C-1 Surabaya, Jawa Timur. Produk yang diproduksi oleh perusahaan ini sebagai berikut : injection timing, ABS rotor sensor, flange, gear kick starter.

1. Mesin Fine blanking adalah mesin press yang mempunyai tekanan atau presure sebesar 800-1100 ton. berfungsi sebagai pencetak produk dari bahan baku coil (gulungan plat besi) diproses di mesin fine blanking sehingga menjadi produk.

2. Belt sander bertujuan untuk menghaluskan permukaan produk.

3. CNC lathe bertujuan untuk memberi chamfer dan membuat groove pada produk.

4. Milling bertujuan untuk memberi chamfer pada lubang yang telah ditentukan pada produk.

5. Mesin pres aida adalah mesin press namun berbeda dengan mesin fine blanking yang mempunyai pressure atau tekanan 800-1100 ton. mesin aida ini hanya mempunyai tekanan atau pressure 30-45 ton yang bertujuan untuk membuat chamfer pada hole atau lubang produk.

6. Rotary grinding berfungsi untuk mengurangi ketebalan produk sekaligus memperhalus permukaan produk.

7. Mesin Brush berfungsi untuk meghilangkan burry sisa dari proses bubut.

Kegiatan diatas mempunyai risiko yang sangat tinggi dan sangat berbahaya. PT. TOSHIN PRIMA FINE BLANKING memiliki karyawan kurang lebih 107 orang sehingga mengharuskan PT.TOSHIN menerapkan program K3 berdasarkan Peraturan Pemerintah No. 50 Tahun 2012 Pasal 5 tentang penerapan sistem manajemen keselamatan dan kesehatan kerja yang menyebutkan bahwa "Setiap perusahaan yang mempekerjakan tenaga kerja sebanyak 100 orang atau lebih atau mengandung potensi bahaya yang ditimbulkan oleh karakteristik proses atau bahan produksi yang dapat mengakibatkan kecelakaan kerja wajib menerapkan Sistem Keselamatan dan Kesehatan Kerja". Namun, saat ini PT. TOSHIN PRIMA FINE BLANKING belum mempunyai divisi $\mathrm{K} 3$, sehingga apabila terjadi kecelakaan kerja yang menangani adalah HRD (Human Resources Department) seperti melakukan pertolongan pertama.

Fokus permasalahan di perusahaan ini adalah timbulnya ancaman keselamatan dan kesehatan kerja. Hasil wawancara terhadap karyawan PT. TOSHIN PRIMA FINE BLANKING 
mengenai kecelakaan kerja, diperoleh data kecelakaan kerja seperti yang tercantum pada tabel 1.1

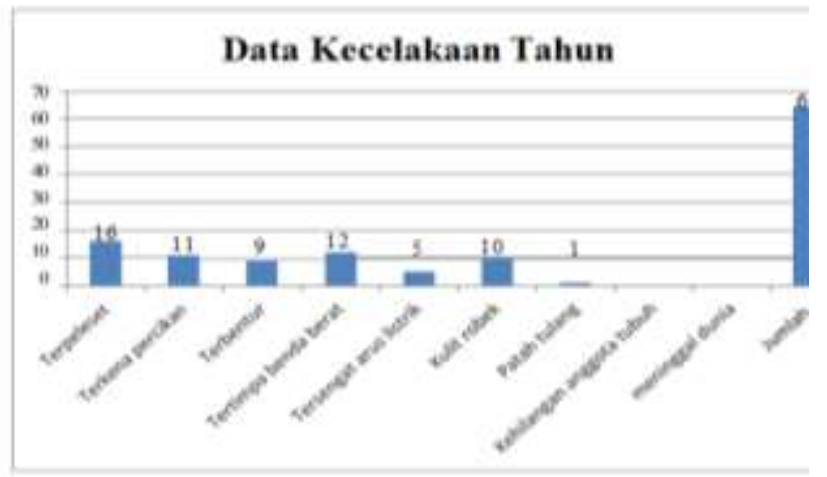

Gasbar 1.1 Kanus Kecelakasn Keja di Ares Produkai nahun 2018

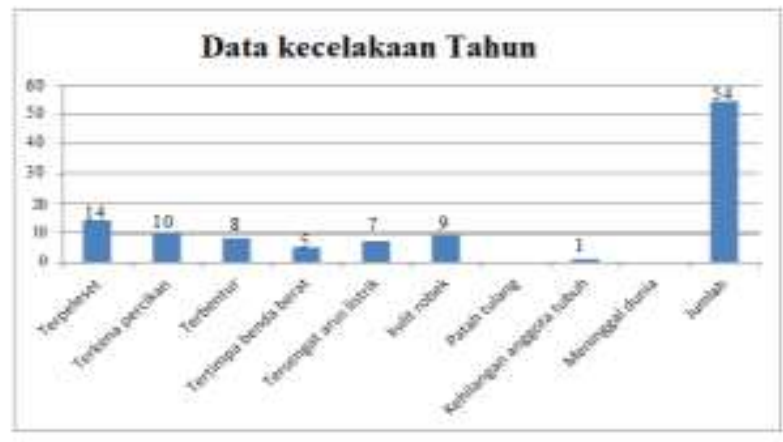

Gambar 1.2 Kasus Kecelakann Keria di Area Prodaksi tahum 2019

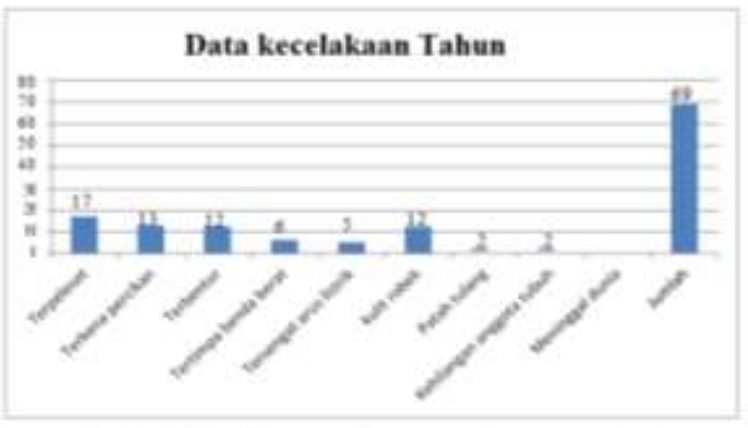

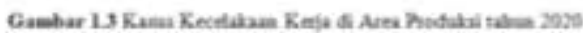

Berdasarkan data yang di dapat, kasus kecelakaan kerja terbanyak terjadi Pada tahun 2018 mengalami penurunan jumlah kecelakaan kerja, tercatat sebanyak 64 kejadian dan pada tahun 2019 turun lagi menjadi 54 kejadian. Akibat dampak dari virus corona yang mana pada tahun 2019 terjadi banyak pengurangan karyawan bahkan perusahaan sempat off tidak produksi selama 1 bulan sehingga tidak terjadi kecelakaan kerja. Pada tahun 2020 keadaan perusahaan mulai beranjak membaik karyawan yang dulu dikeluarkan dipanggil lagi untuk bekerja bahkan merekrut karyawan baru karena jumlah order yang meningkat.

Hal itu mungkin yang membuat kenaikan kecelakaan kerja karena banyak pegawai baru yang masih baru bekerja dan belum paham bahaya dalam pekerjaan. Tercatat pada tahun 2020 kejadian kecelakaan kerja sebanyak 69 kejadian.

Hal ini menunjukkan bahwa tingginya potensi kecelakaan kerja dalam aktivitas setiap bagian atau mesin. Dan kecelakaan yang sering terjadi disetiap tahun adalah terpeleset. Disini menunjukan kurang maksimalnya evaluasi tentang kecelakaan kerja karena dari tahun ketahun masih terjadi kecelakaan kerja yang sama dengan angka kejadian paling tinggi pada tiap tahunnya.

Berdasarkan latar belakang yang ada, penelitian ini bertujuan untuk meminimalisir dan mencegah kecelakaan kerja. Dengan melakukan langkah penanganan dan melakukan analisis untuk mengetahui apa saja faktor yang menimbulkan terjadinya risiko kecelakaan kerja menggunakan metode JSA (Job Safety Analysis ) dan HIRARC (Hazard Identification, Risk Assessment and Risk Control)

Untuk tahap identifikasi bahaya penelitian ini menggunakan metode Job Safety Analysis dengan tujuan untuk mengetahui setiap bahaya yang ada pada proses produksi dari awal hingga akhir proses produksi. Sehingga setelah mengenali jenis bahaya yang ada, perusahaan dapat menempatkan posisi risiko dan menentukan bagaimana cara menangani risiko yang tepat. 
sedangkan Metode HIRARC (Hazard Identification, Risk Assessment and Risk Control) adalah metode identifikasi yang digunakan untuk meninjau hazard suatu operasi atau proses secara sistematis, teliti dan terstruktur yang dapat menimbulkan resiko merugikan bagi manusia, fasilitas, lingkungan, atau sistem yang ada serta menjelaskan penanggulangan resiko. Tingkat/level implementasi suatu program berdasarkan hirarc dikatakan efektif atau tidak, diketahui melalui kombinasi tingkat kinerja program dan tingkat kecelakaan. (Deddi Septian Purnama 2015) Dan hasil dari metode ini dapat ditemukan penyebab terjadinya kecelakaan kerja dan membuat rekomendasi pengendalian resiko berdasarkan bahaya yang teridentifikasi.

\section{TINJAUAN TEORITIS}

Job Safety Analysis

Menurut friend dan kohn (2006), JSA adalah sebuah teknik analisis bahaya yang digunakan untuk mengidentifikasi bahaya yang ada pada pekerjaan seseorang dan untuk mengembangkan pengendalian yang tepat untuk mengurangi risiko. JSA umumnya tidak digunakan untuk melakukan peninjauan desain atau memahami bahaya dari suatu proses kompleks.

Hazard

Menurut Supriyadi dkk, (2017), hazard (bahaya) adalah suatu kondisi atau tindakan atau potensi yang dapat menimbulkan kerugian terhadap manusia, harta benda, proses, ataupun lingkungan. Bahaya adalah sumber atau sebuah situasi yang membahayakan dan memiliki potensi untuk menyebabkan kecelakaan atau penyakit pada manusia, merusak peralatan dan merusak lingkungan (Halim dkk, 2016).
Kecelakaan kerja

Kecelakaan menurut Sulaksmono, dalam Anizar, (2012) adalah suatu kejadian tak diduga dan tidak di kehendaki yang mengacaukan proses suatu aktivitas yang telah diatur. Kecelakaan tanpa di sangkasangka dan dalam sekejap mata, dan setiap kejadian terdapat empat faktor yang bergerak dalam satu kesatuan berantai yaitu lingkungan, bahaya, peralatan dan manusia. Kecelakaan akibat kerja adalah kecelakaan yang berhubung dengan hubungan kerja pada perusahaan. Hubungan kerja dalam arti, bahwa kecelakaan terjadi dikarenakan oleh pekerjaan atau pada waktu melaksanakan pekerjaan.

OHSAS 18001:2007

Occupational Health And Safety Assesment Serries 18001:2007 (OHSAS 18001, 2007) adalah salah satu manajemen K3 yang berlaku secara global. OHSAS 180000 terdiri dari dua bagian yaitu OHSAS 18001 dan OHSAS 18002. OHSAS 18001 memuat ketentuan tentang spesifikasi dari sistem manajemen K3 yang harus diterapkan dalam perusahaan guna menciptakan aktivitas kerja yang efisien. OHSAS 18002 memuat seluruh persyaratan dan pedoman yang menunjukan cara pendaftaran serta pengimplementasiannya. Berdasarkan OHSAS 18001:2007 adalah HIRARC menjadi salah satu persyaratan yang harus ada dalam menerapkan sistem manajemen keselamatan dan kesehatan kerja (SMK3) (Halim, 2016).

Risiko

Menurut OHSAS 18001, risiko adalah kombinasi dari kemungkinan terjadinya kejadian berbahaya atau paparan dengan keparahan dari cidera atau gangguan kesehatan yang disebabkan oleh kejadian atau paparan tersebut Sedangkan manajemen risiko adalah suatu proses untuk mengelola risiko yangada dalam setiap kegiatan 
(Ramli,2010).

Manajemen Risiko

Manajemen risiko keselamatan adalah suatu upaya mengelola risiko untuk mencegah terjadinya kecelakaan yang tidak diinginkan secara komprehensif, terencana dan terstruktur dalam suatu sistem yang baik (Ramli, 2010). Namun pendapat lain mengatakan bahwa manajemen risiko adalah suatu kegiatan yang dilakukan untuk menanggapi risiko yang telah diketahui (melalui rencana analisis risiko atau bentuk observasi lain) untuk meminimalisasi konsekuensi buruk yang mungkin muncul (Webb, 1994).

Sistem Manajemen Keselamatan dan

Kesehatan Kerja (SMK3)

Sistem manjemen keselamatan dan kesehatan kerja (SMK3) merupakan bagian dari sistem manajemen secara keseluruhan yang meliputi struktur organisasi, perencanaan, tanggung jawab, pelaksanaan, prosedur, proses dan sumber daya yang dibutuhkan bagi pengembangan, penerapan, pencapaian, pengkajian dan pemeliharaan kebijakan keselamatan dan kesehatan kerja dalam rangka pengendalian risiko yang berkaitan dengan kegiatan kerja guna terciptanya tempat kerja aman, efisien, dan efektif.
Konsep HIRARC

Hazard Identification Risk Assesment and Risk Control (HIRARC) adalah salah satu persyaratan dalam penerapan SMK3 berdasarkan OHSAS 18001:2007. Pada klausul 4.3.1 OHSAS 18001:2007 organisasi harus menetapkan prosedur mengenai identifikasi bahaya (hazard idnetification), penilaian risiko (risk assesment) dan pengendalian risiko (risk control) (Ramli, 2010).

Menurut Departement of Occupational Safety and Health Malaysia (2008), dalam pelaksanaan HIRARC memiliki tujuan sebagai berikut :

1. Mengidentifikasi semua faktor yang bisa menyebabkan kerusakan terhadap pekerja dan lain-lain.

2. Kemungkinan perusahaan akan merencanakan, memperkenalkan dan memantau langkah pencegahan supaya bisa memastikan bahwa risiko dikendalikan secara memadai.

Berikut ini matrik yang digunakan untuk penilaian dalam jurnal penyusunan HIRARC 
Tabel 2. I Skala "Likelihood"

\begin{tabular}{|c|c|l|}
\hline Tingkat & Deskripsi & \multicolumn{1}{c|}{ Keterangan } \\
\hline 5 & Most Likely & $\begin{array}{l}\text { Hasil yang paling mungkin dari bahaya yang terjadi } \\
\text { Berulangkali }\end{array}$ \\
\hline 4 & Possible & Memiliki peluang bagus untuk terjadi dan bukan biasa \\
\hline 3 & Conceivable & Mungkin terjadi suatu saat nanti \\
\hline 2 & Remote & Belum diketahui terjadi setelah bertahun-tahum \\
\hline 1 & Inxonceivable & Praktis tidak mungkin dan tidak pernah terjadi \\
\hline Sumber: Departemen Of Occupational Safety and Health Malaysia (200s)
\end{tabular}

Tabel 2. 2 Skala "Severity"

\begin{tabular}{|c|c|l|}
\hline Tingkat & Deskripsi & \multicolumn{1}{|c|}{ Keterangan } \\
\hline 5 & Catastrophic & $\begin{array}{l}\text { Banyak korban jiva, kerusakan properti yang tidak bisa } \\
\text { diperbaiki dan produktivitas }\end{array}$ \\
\hline 4 & Fatal & $\begin{array}{l}\text { Kira-kira satu kecelakaan besar pada objek ketika } \\
\text { bahaya realisasikan }\end{array}$ \\
\hline 3 & Serious & Cedera non-fatal, cacat tetap \\
\hline 2 & Minor & Cacat tapi bukan luka permanen \\
\hline 1 & Negligible & $\begin{array}{l}\text { Lecet kecil, memar, 1uka, pertolongan pertama pada } \\
\text { Kecelakaan }\end{array}$ \\
\hline Sumber: Departemen Of Occupational Safety and Health Malaysia (2008)
\end{tabular}

Setelah didapatkan nilai likelihood dan severity selanjutnya menentukan nilai risiko untuk mendapatkan level risiko. Untuk mendapatkan nilai risiko dihitung dengan menggunakan rumus sebagai berikut :

\section{Risk $=$ likelihood $x$ severity}

Sumber : Departemen Of Occupational Safety and Health Malaysia (2008)

Nilai risiko selanjutnya dimasukkan kedalam risk matrix untuk mengetahui level risiko dari bahaya yang telah teridentifikasi. Skala Risk Matrix dapat dilihat pada tabel di bawah ini :

Tabel 2. 3 Skala "Risk Matrix"

\begin{tabular}{|c|c|c|c|c|c|}
\hline \multirow{2}{*}{ Likelihood } & \multicolumn{5}{|c|}{ Severity } \\
\cline { 2 - 6 } & 1 & 2 & 3 & 4 & 5 \\
\hline 5 & 5 & 10 & 15 & 20 & 25 \\
\hline 4 & 4 & 8 & 12 & 16 & 20 \\
\hline 3 & 3 & 6 & 9 & 12 & 15 \\
\hline 2 & 2 & 4 & 6 & 8 & 10 \\
\hline 1 & 1 & 2 & 3 & 4 & 5 \\
\hline
\end{tabular}

Sumber : Departemen Of Occupational Safety and Health Malaysia (2008)

Keterangan :

a) Hijau-Low Risk : Risiko dapat diterima, pengendalian tambahan tidak diperlukan. Dengan nilai risiko 1-4.

b) Kuning-Moderate Risk : 
Memerlukan pendekatan yang direncanakan untuk mengendalikan bahaya dan berlaku tindakan sementara jika diperlukan. Dengan nilai risiko 5-12

c) Merah-High Risk : Kegiatan tidak boleh dilaksanakan atau dilanjutkan sampai risiko telah direduksi. Jika tidak memungkinkan mereduksi risiko, maka pekerjaan harus segera dihentikan. Dengan nilai risiko $15-25$.

\section{METODE PENELITIAN}

Metode yang digunakan dalam penelitian ini adalah metode deskriptif dengan pendekatan kualitatif yang ditujukan untuk mendapatkan informasi dan mengkaji permasalahan mengenai risiko keselamatan pekerja yang bekerja di area produksi. Penlitian ini dilakukan di PT. TOSHIN PRIMA FINE BLANKING yang berlokasi di Jl. Margomulyo indah C-1 manukan wetan, tandes Surabaya. PT. TOSHIN PRIMA FINE BLANKING adalah sebuah pabrik yang bergerak di bidang manufacturing. Waktu yang diperlukan untuk menyelesaikan penelitian ini selama 2 bulan berlangsung dari bulan Juni hingga Juli. Teknik pengumpulan data melalui observasi, wawancara, studi dokumentasi, dan penyebaran kuesioner. Obyek penelitian ini adalah potensi risiko dan sumber bahaya yang terjadi dari proses produksi yang berada pada mesin Fine blanking, Belt sander, CNC lathe, Milling, Mesin pres aida, Rotary grinding dan Mesin Brush. Responden dari penelitian ini adalah seluruh karyawan yang bekerja pada setiap mesin di area proses produksi yang sudah berpengalaman dan dianggap sudah memahami kegiatan yang sudah menjadi

pekerjaannya selama dibidang nya.

\section{HASIL DAN PEMBAHASAN}

Identifikasi bahaya dilakukan dengan menggunakan metode brainstorming dengan penyebaran kuisoner kepada setiap bagian yang sudah dirasa menguasai di bidangnya masingmasing dan supivisor produksi, hasil identifikasi bahaya dan potensi bahaya yang berhubungan dengan setiap langkah proses kerja pada area proses produksi yaitu FB800T, Belt Sander, CNC Lathe, Milling, Mesin Press Aida, Rotary Grinding dan Mesin Brush.

Penilaian risiko ini menganalisis pada area proses produksi yang bertujuan untuk mengetahui sejauh mana tingkat kejadian dan tingkat keparahan suatu bahaya kecelakaan. Parameter yang digunakan untuk melakukan penilaian risiko adalah perkalian antara likelihood dengan severity. Dari hasil penilaian risiko ini didapatkan level risiko dan pengendalian risiko. Nilai dari likelihood dengan severity didasarkan dari brainstorming dengan supervisor produksi yang sudah berpengalaman dalam bidangnya.

Pengendalian risiko ini bertujuan untuk menangani risiko berdasarkan level risiko dari masing-masing bahaya yang ada pada area proses produksi. pengendalian risiko pada penelitian ini berdasarkan ketentuan pada OHSAS 18001:2007 dimana pengendalian risiko ini di klasifikasikan menjadi lima macam pengendalian yaitu eliminasi (menghilangkan bahaya), subtitusi (mengganti bahan, alat atau cara kerja supaya lebih aman), pengendalian teknik (memperbaiki atau menambah suatu sarana atau peralatan teknis, seperti penambahan peralatan, perbaikan pada desain komponen, mesin dan material), penegendalian administratif (membuat suatu peraturan, peringatan rambu, 
prosedur, instruksi kerja yang lebih aman atau pemeriksaan kesehatan), penggunaan alat pelindung diri.

\section{KESIMPULAN}

Berdasarkan hasil dari penelitian dengan menggunakan metode $J o b$ Saffety Analysis dan Hazard Identification Risk Assesment And Risk Control pada perusahaan PT. Toshin Prima Fine Blanking maka dapat diambil kesimpulan bahwa identifikasi bahaya menggunakan metode JSA terjadi karena faktor manusia, mesin dan manajemen. Sedangkan hasil penilaian risiko dengan menggunakan metode HIRARC dapat di ketahui nilai resiko bahaya kecelakaan high risk atau risiko tinggi terletak di mesin FB800T, MILLING, mesin AIDA dan ROTARY GRINDING. Hasil pengendalian risiko dengan menggunakan metode HIRARC di dapat usulan pengendalian risiko kecelakaan yang ada di setiap mesin yang mempunyai kategori bahaya high risk atau risiko tinggi

\section{SARAN}

1. Untuk Perusahaan

Di harapkan pihak PT.Toshin Prima Fine Blanking dapat menerima dan mengaplikasikan rekomendasi pengendalian risiko dari penelitian ini dan membentuk divisi K3 supaya penanganan kesehatan, keselamatan kerja di perushaan ini lebih baik dari sebelumnya.

2. Untuk Penelitian Selanjutnya Untuk penelitian selanjutnya diharapkan melakukan penelitian tidak hanya pada tahap rekomendasi risk control, tetapi sampai tahap implementasi pemantauan dari risk control.

\section{DAFTAR PUSTAKA}

Departement of Occupational safety and
Health Ministry of Human Resources. Guedline for Hazard Identification, Risk Assesment and Risk Control. Malaysia. JKKP DP 127/789/4-47 ISBN 978-983-2014-62-1. 2008.

OHSAS 18001. Occupational Health and Safety Management System Guideline For The Implementation of OHSAS. 2007

Purnama, Deddi Septian, Analisis Penerapan Metode Hirarc (Hazard Identification Risk Assessment And Risk Control) Dan Hazops (Hazard And Operability Study) Dalam Kegiatan Identifikasi Potensi Bahaya Dan Resiko Pada Proses Unloading Unit Di PT. Toyota Astra Motor, Jakarta, Purnama, 2015.

Rusmayani, Pengaruh Kesehatan Dan Keselamatan Kerja Terhadap Semangat Kerja Dan Prestasi Kerja Karyawan Di PT. Ramajaya Pramukti Kabupaten Kampar, Riau, Universitas Pekanbaru, 2017.

Supriyadi, Ramdan, Identifikasi bahaya gan Penilaian Risiko pada Divisi Boiler Menggunakan Metode Hazard Identification Risk Assesment and Risk Control (HIRARC). Journal of Industrial Hygiene and Occupational Health, Vol. 1, No. 2, ISSN 2527 4686. 2017.

Supriyanto, Erlian. Manufaktur Dalam Dunia Teknik Industri, Bandung, Fakultas Teknik Universitas Nurtanio, 2013.

Wijanarko , Edo, Analisis Risiko Keselamatan Pengunjung Terminal Purabaya Menggunakan Metode Hirarc (Hazard Identification, Risk Assessment 
E -ISSN : 2746-0835

Volume 2 No 2

JUSTI (Jurnal Sistem Dan Teknik Industri)

And Risk Control), Surabaya,

Fakultas Teknologi Industri

Institut Teknologi Sepuluh

Nopember, 2017.

https://www.safetysign.co.id/news/342/Ba

gaimana-Melaksanakan-Job-

Safety-Analysis-JSA-yang-Efektif-

Ikuti-5-Langkah-Penting-Ini 